\title{
Electrizarte: Combining Engineering Education, ArTS AND SOCIAL OUTREACH IN AN EXTRA-CURRICULAR ACTIVITY
}

\author{
Teodoro Willink ${ }^{1}$, Gustavo Núñez ${ }^{2}$ and Lochi Yu \\ Faculty of Engineering, University of Costa Rica. \\ 1twillink@eie.ucr.ac.cr, ${ }^{2}$ gnunez@eie.ucr.ac.cr
}

\begin{abstract}
In the Electrical Engineering undergraduate program of the University of Costa Rica, most of the design and analysis projects are guided, structured and related to a specific topic, limiting technical content and machining the way problems are solved, which in turn, restricts the motivated student creativity.

The ElectrizArte Project provides the opportunity to develop both technical and not-technical skills in a extracurricular enviroment. As the main theme, ElectrizArte allows students to design, implement, and operate projects that combine engineering with art, taking advantage of the particular situation that many of the students participating in the project, have interest in art in general, or practice some artistic activity.
\end{abstract}

Keywords: Extra-curricular, Art, Motivation, Electronic.

\section{INTRODUCTION}

The Electrical Engineering undergraduate program of the University of Costa Rica, besides the final bachelor project and a few other projects, has a lack of spaces to develop analysis and design projects in an open and interdisciplinary environment. Most of program courses have a well - defined structure and thematic range that may be appropriate for the curriculum, but also are limited in terms of comprehensive analysis and creativity.

Besides this limitation, we have also observed a low level of motivation among many electrical engineering undergraduate students. This lack of interest appears in different amounts, but given the active inquiry - based nature of engineering education, in one way or another, it hinders the student's learning process. Increasing their motivation is then essential to improve the learning process in our engineering undergraduate program [6].

The ElectizArte project aims to give students an opportunity to develop open and comprehensive engineering projects, in a field that enhances their motivation: art. Different fields of art, including musical, graphical and performing arts, have shown to be of interest among many of our electrical engineering students. By matching student's interests in art, with his skills in engineering, ElectrizArte provides a learning environment that is highly technical and self-motivated [5].
Several projects at other universities have tried to merge engineering with arts. Some include the mixing of engineering and art students in the building of the cauldron of the Canadian Games [2]. Other approaches include formally educating engineering students in the arts, as part of an official elective course [3]. ElectrizArte has a different profile: it consists of an extra-curricular activity that allows proposing and developing projects almost freely, with a low level of guidance in order to promote motivation and self-learning.

The results reached with this project would help to introduce some of the methodologies actually used in ElectrizArte, in courses belonging to the undergraduate program, increasing the opportunity to develop projects with a higher analysis, comprehension and interdisciplinary content.

\section{THE ELECTRIZARTE PROJECT}

\subsection{Concepts and Objectives}

The ElectrizArte project was conceived as a learning environment that allows electrical engineering undergraduate students, to develop engineering skills and exploit their creativity through projects that combine engineering with art. For an electrical engineering undergraduate student with interest in art, this combination links his abilities with his interest, enhancing considerably his learning process. For example, a firstyear student with strong artistic abilities can play and learn from a new electronic instrument developed and built by a last-year student that is interested in music but doesn't know how to play. Figure 1 shows the conceptual match of interests and abilities in ElectrizArte.

ElectrizArte was also conceived as an extra-curricular activity, in order to provide an opportunity for students to work in an open project, stregthening the knowledge they have obtained from their courses, as well as obtain new skills that are not part of their curriculum (e.g. soldering). Moreover, students can develop competences that may not be normally addressed in ordinary courses, such as leadership, teamwork, project management and creative thinking. These attribute not only are as valuable in the labor world as technical skills, but also have become an important requirement by several accreditation bodies [1] 


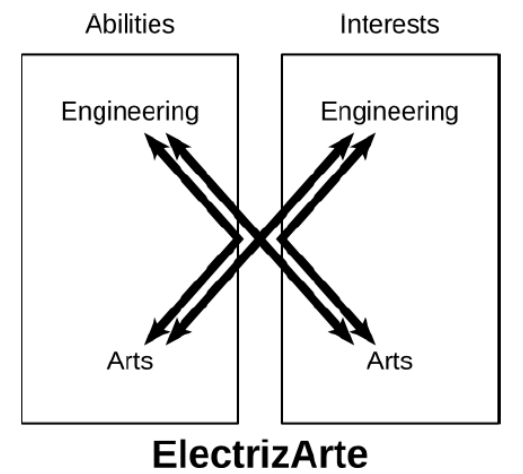

Figure 1. Conceptual match of interest and abilities in Electrizarte.

Furthermore, ElectrizArte has a vision of using engineering to magnify the perception of art and, conversely, using art to show the capabilities of engineerging. The first goal aims to use the creative power of students to find new and interesting ways to better express themselves in an artistic way (e.g. shine a light every time a string is played). The second goal aims to educate society about engineering and promote a better understanding towards the abilities and work of engineers.

Finally, it is important to highlight that the learning process is especially fruitful when the learner is consciously involved in the design and implementation of a project that can be exhibited, tested, discussed, examined or admired [1]. ElectrizArte provides a flexible and comprehensive environment that involves students in these kinds of projects.

\subsection{Methodology}

The methodology in ElectrizArte is based on three principal steps: design, implementation and operation. In the entire process, the student need to define, design, execute and test the project, with the possible guidance of the professors involved. Finally, the student presents the project.

The development of the student's creativity is one of the main goals in ElectrizArte. In ordinary courses, there is seldom a project that they can freely propose. In ElectrizArte, students propose either individually or in groups, an idea for a project (e.g. a new musical instrument), and the professor discusses with them its difficulty and outreach. Together they define a project according to the abilities, learning styles, interests and goals of the students, so that they can successfully carry out the design, implementation and testing stages. If a student wants to participate in ElectrizArte but doesn't have an idea of his own, he can either join an existing project or start a new one, based on an idea from another student or professor.

ElectrizArte has relatively frequent presentations, which consist mostly in two parts. Firstly a musical show, where the students play some popular and original songs, using the projects they developed (for example, musical instruments) and traditional musical instruments for support; then, the audience is invited to examine and appreciate the different ElectrizArte projects, allowing them to make questions to the performers and constructors of each project. These presentations impose two types of challenges: artistical (the performance has to be rehearsed) and technical (the projects must be finished on time and work properly, as with engineering projects in real life). Once a project is finished, it remains as a part of ElectrizArte and can be modified and updated by its creators or a new group of students.

This methodology results in an active learning model that follows a constructivism approach in the sense that in encourages discovery, hands - on experiential, collaborative, project - based and task - based learning [4]. With the wide spectrum of guidance available, the motivation and learning environment can be maintained, as well as a steady project progress.

\subsection{Development and excecution}

Since 2011, ElectrizArte has worked with more than 50 electrical engineering undergraduate students, who have different artistic and engineering abilities and interests: some perform music, some give ideas for new musical instruments, some build them, some do everything. In this process, several projects have been started and many have been completed, and numerous presentations that range from in-house short performances, to regional and national events.

The Electrizarte project has had since its creation in 2011, three main stages. The first stage, from 2011 to 2012, was a pilot phase that focused mostly on the projects, and thus involved many students presentations and developments. The second stage, in 2013, has involved less students and developments, but has emphasized more on the educational aspects of ElectrizArte. The third stage, since 2014 to the present, the amount of students involved in the project has increased and most of them collaborate in at least two sub-activities of the project. In the same way, the amount of presentations has increased too.

Freedom to participate at many different levels was given during the first stage, while on the second stage a stronger commitment to the projects has been encouraged. This way, during 2011 and 2012 the number of students involved in ElectrizArte changed considerably, as some were lead designers of a long project while others participated, occasionally, solving specific problems. Since 2013, students have been encouraged to be part of ElectrizArte for at least one project cycle of definition, design, execution, testing and presentation, ensuring a stringer educational value in their participation and facilitating its assessment. 
Therefore, the number of students involved in the first stage and their level of participation has been hard to measure. Table 1 shows the amount of students interested in joining ElectrizArte at the beginning of each year of the first stage. About half ot those students sustained their efforts until the end of the year. The number of students involved in at least one project cycle during each term of 2013 is shown in Table 2.

Table 1: Amount of students interested in ElectrizArte during the first stage.

\begin{tabular}{|c|c|}
\hline Year & Interested students \\
\hline 2011 & 33 \\
\hline 2012 & 14 \\
\hline
\end{tabular}

Table 2: Amount of students involved in ElectrizArte during the second stage

\begin{tabular}{|c|c|c|c|}
\hline Year & $\begin{array}{c}\text { New } \\
\text { students }\end{array}$ & $\begin{array}{c}\text { Students } \\
\text { from last } \\
\text { term }\end{array}$ & Total \\
\hline I-2013 & 6 & 0 & 6 \\
\hline II-2013 & 6 & 6 & 12 \\
\hline
\end{tabular}

Some projects developed by the ElectrizArte students during the first stage are: two LED cubes, a Tesla Coil, a laser-based harp (Lumint, laser for musical interface), a body gesture-based synthesizer, a vibration-sensible lighting set for percussion and building sized VU-meter. Most of these projects have been presented in several musical performances prepared by the students themselves. The ElectrizArte presentations include a campus-wide open house event (Expo UCR, see Figure 2), a TEDx event (see Figure 3 ) and visits to campuses of three different universities (see Figure 4).

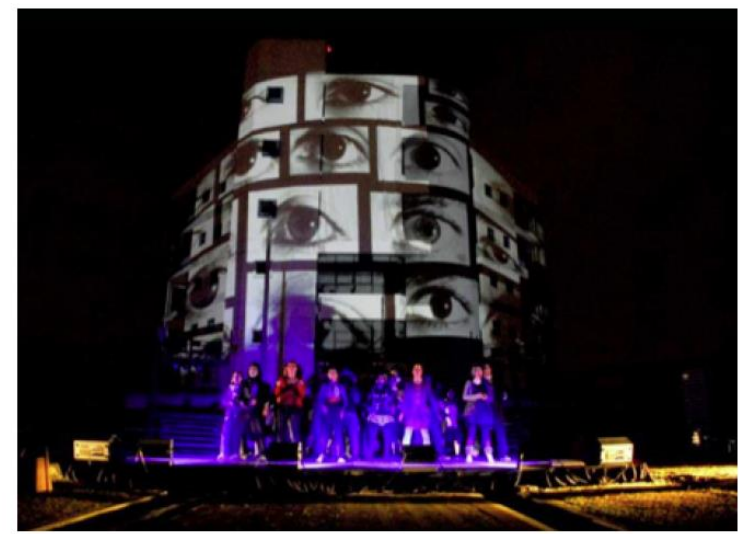

Figure 2. Performance of ElectrizArte in ExpoUCR 2011

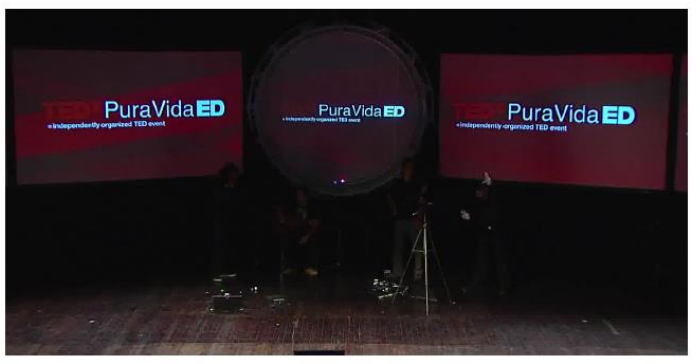

Figure 3. Performance of ElectrizArte in TEDx PuraVidaED.

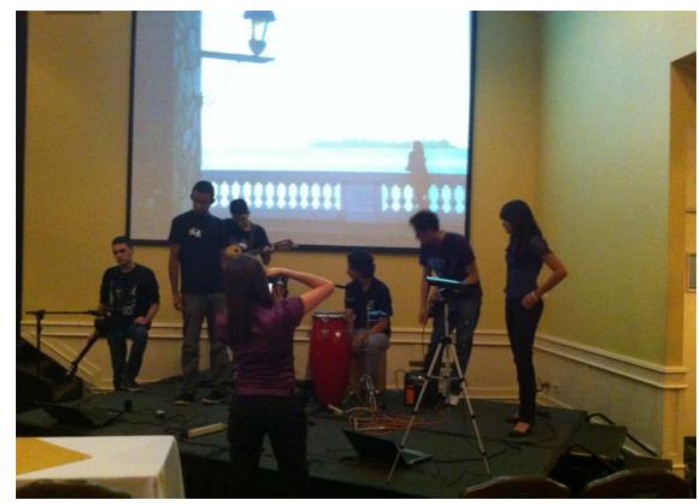

Figure 4. Performance of ElectrizArte in other campuses

In the second stage, the work has included updates to the existing projects (like support for sound synthesis using the Tesla Coil) and some new projects, like a tone matrix. The presentations have included in-houses performances, as well as regional events and tours to other campuses of the university.

In the third stage, started the design of new instruments, a group of digital animation and some music classes for students who want to play the instruments that they made but don't have any musical knowledge. The amount of students interested in ElectrizArte increased in this stage, and most of them are still involved in the project at different levels. Some of the instruments that have been developed, and others that are still in process, are: an electronic drum set made of acrylic, a Tablet/cellphone-based guitar and a dynamic lighting control for orchestra. In this stage, the participation in the university activities increased. Electrizarte participated in technological and artistic activities organized by our unverisity, playing little concerts and showing some projects.

\section{RESULTS}

Four main results have been obtained from the ElectrizArte project so far. First, the motivation of the students has been satisfactorily increased. After the first stage, a short survey was given to seven students that had 
had different levels of participation. The survey consisted in six open questions about how satisfied they were with their participation in Electrizarte.

Second, there is a considerable portion of electrical engineering undergraduate students that have a strong interest or ability in arts. In the first stage, 47 students out of about 400 total active students worked with ElectrizArte in one way or another, which shows that at least $10 \%$ of the student population had a strong interest towards art. For these students, the artistic interests ranged from music to graphical design to performing arts.

Third, we observed that several projects proposed by the students address skills and knowledge that are not covered in the ordinary courses. For example, the Tesla Coil, which construction is by itself very educational, imposed a very new challenge with its proposed improvement to produce different musical tones. Also, the Lumint involved the use of computer vision libraries, such as OpenCV, that are not covered in any particular course in our curriculum.

Fourth, the motivation has expanded from the extracurricular environment of ElectrizArte to some curricular activities. In some courses, especially laboratories, several students have directed their final projects towards the combination of engineering and arts.

The main unsatisfactory result we have had is the low number of students that decided to join ElectrizArte for the second stage. Even though the ones that were involved were very committed, most of the students that have also shown interest, have no participated and complained about their low availability of time for extra-curricular activities due to their busy schedule.

\section{CONCLUSIONS}

Electrizarte is still work in progress, but the work presented here shows that the undergraduate engineering students can learn important technical skills in a selfmotivated environment outside their classrooms. This creates and opportunity to link the students abilities with their interests, increase their motivation and promote nontechnical skills that are sometimes overlooked. This way, participation in ElectrizArte becomes of strong educational value for students.

Besides, professor-student relationships can improve much more than with regular classwork or laboratory experience. ElectrizArte helps "legitimize" the role of the professor, so that he is no seen only as someone demanding answers in an exam, but seen truly as someone devoted to the learning experience of the student.

Moreover, ElectrizArte has also managed to, through the presentations; show the general public some of the technical skills that the electrical engineering students possess. These presentations help illustrate what an electrical engineer can do, to people that maybe by other means would not realize.
Finally, there is not much tradition in our university (especially for engineering students) to do much academic activity outside the regular boundaries of a registered course, as opposed to other majors such as arts and medicine. Then, ElectrizArte should not only attempt to improve the learning process of electrical engineering students, but also promote this tradition of joining extracurricular, university-run academic activities.

\section{References}

[1] Seymour Papert and Michael Resnick, Constructionsm: A New Opportunity for Elementary Science Education. Proposal to the National Science Foundation. Cambridge, MA.

[2] Alain Desrochers and Jim Benson, "Collaborative Project: Crossing Borders Between Arts and Engineering" Proc. 2013 Canadian Engineering Education Association (CEEA13). Montreal, Canada. Available as of April 15, 2015 from http://library.queensu.ca/ojs/index.php/PCEEA/article/view/ $4828 / 4775$

[3] Ken Tallman, "Educating Engineering Students in the Arts" in Proc. 2013 Canadian Engineering Education Association (CEEA13). Montreal, Canada.

Available as of March 23, 2015 from

http://library.queensu.ca/ojs/index.php/PCEEA/article/view/ $4827 / 4774$

[4] Ernest von Glaserfeld, "Constructivism in Education" in T. Husen \& T.N. Postlethwaite, (eds.)(1989) The International Encyclopedia of Education, Supplement Vol.1. Oxford, New York: Pergamon Press, 162-163.

Available as of April 2, 2015 from

http://www.univie.ac.at/constructivism/EvG/papers/114.pdf

[5] María Rianudo,Analía Chiecher y Danilo Donolo, "Motivación y usos de estrategias en estudiantes universitarios. Su evaluación a partir del Motivated Strategies Learning Questionnaire" Anales de psicología vol 19, $\mathrm{n}^{\circ} 1,107-119$. Murcia, España.

Available as of March 29, 2015 from www.um.es/analesps/v19/v19_1/11-19_1.pdf

[6] Alejandro Anaya-Durand y Celina Anaya-Huertas, "Motivation just to approve? Or for learning! Strategies of learning motivation for the students" UNAM, Mexico. Available as of March 29, 2015 from http://web.imiq.org/attachments/345_5-14.pdf 